\title{
Isotope characterisation of deep aquifers in the Gwda catchment, northern Poland
}

\author{
Tomasz Kotowski* \& Stefan Satora \\ University of Agriculture, Department of Sanitary Engineering and Water Management, al. Mickiewicza 21, \\ 31-120 Kraków, Poland \\ * corresponding author, e-mail: kotowski.tomasz@gmail.com
}

\begin{abstract}
We present the results of isotope measurements $\left(\delta^{18} \mathrm{O}, \delta \mathrm{D}, \delta^{13} \mathrm{C}_{\mathrm{DIC}}\right.$ and $\left.{ }^{14} \mathrm{C}\right)$ and chemical analyses (TDS, TOC, $\mathrm{HCO}_{3}^{-}$, $\mathrm{SO}_{4}{ }^{2-}, \mathrm{Cl}^{-}, \mathrm{NO}_{3}{ }^{-}, \mathrm{NH}_{4}{ }^{+}, \mathrm{Ca}^{2+}, \mathrm{Mg}^{2+} \mathrm{Na}^{+}$and $\mathrm{K}^{+}$) conducted on groundwater samples collected from deep Cenozoic aquifers. These aquifers are the basic source of drinking water at numerous localities within the study area in northern Poland. Most of the $\delta^{18} \mathrm{O}$ determinations are characterised by low variability (i.e., $>70$ per cent of $\delta^{18} \mathrm{O}$ are between $-9.5 \%$ and $-9.2 \%$ ). In most cases tritium activity was not detected or its content slightly exceeded the uncertainty of measurement (from \pm 0.3 T.U. to \pm 0.5 T.U.). On average, ${ }^{14} \mathrm{C}$ activity is twice higher than that under similar conditions and in hydrogeological systems. The $\delta^{13} \mathrm{C}_{\mathrm{DIC}}$ values fall within the $-13.6 \%$ o to $-12.8 \%$ o range. A slight variability is observed when considering all isotope and chemical data within the study area and under these hydrogeological conditions. In general, the results of isotope and chemical analyses seem to be homogeneous, indicating the presence of closely similar groundwaters in the system, irrespective of geological formation. It is likely that there is a significant hydraulic connection between shallow and deep aquifers in the Gwda catchment, which indicates the potential for seepage of pollutants from shallow Pleistocene to deep Miocene aquifers. This can endanger the latter by e.g., high concentrations of $\mathrm{NO}_{3}^{-}$, $\mathrm{SO}_{4}^{2-}$ and $\mathrm{Cl}^{-}$ions from shallow aquifers within the Gwda catchment.
\end{abstract}

Keywords: Cenozoic aquifers, groundwater dating, stable isotopes, radiocarbon

\section{Introduction}

The Miocene aquifer in the catchment of the River Gwda (northern Poland), is part of an extensive reservoir of good-quality groundwater (II and III classes, according to Rozporządzenie, 2008) with a range that is much greater than the catchment area discussed (Kotowski \& Satora, 2012). This aquifer is the basic source of drinking water at numerous localities. The present paper discusses results of isotope measurements and chemical analyses performed for groundwater samples taken mainly from the Miocene aquifer and locally from the Lower Pleistocene aquifer. Until now, analysis of $\delta^{13} \mathrm{C}$ and ${ }^{14} \mathrm{C}$ was never conducted for the Miocene aquifer in the River Gwda catchment area.
The existing knowledge of the Miocene aquifer in the Gwda catchment comprises regional and cartographic works or those related to the documentation of groundwater intakes. These previous papers (e.g., Kachnic \& Kotowski, 2004a, b) focused on a draft description of the abundance and dynamics of Miocene aquifers and also on the assessment of their quality and related threats.

A preliminary analysis of groundwater circulation systems and hydrodynamic conditions using hydrodynamic cross sections in the western part of the Gwda catchment was presented by Kotowski \& Śmietański (2010). Later, processes affecting the chemical composition of groundwater in the southeastern part of this catchment were studied by Kotowski \& Kachnic (2007). These studies were 
supplemented by Kotowski \& Burkowska (2011), who discussed issues related to the genesis of sulphates in the Lower Pleistocene aquifer in the area of a buried valley near Wysoka. An analysis of groundwater pollution has shown that a significant number (> 30 per cent) of shallow aquifers within the Gwda catchment are anthropogenically polluted (Kotowski, 2009).

Taking the mutually noted observations into account within the context of water management and supply, these aquifers have been poorly examined, which is why it is important to understand in detail the groundwater conditions within the study area. Determination of the isotope composition of groundwaters from deep and shallow aquifers is significant for our understanding of the groundwater circulation system within the area. Another key research task is to estimate of the age of groundwater in deep aquifers. This can be significant in the future because the shallow aquifers are significantly polluted by man on a local level. Overall, the primary twofold aim of the present study is to investigate the connection between shallow and deep aquifers and to describe its isotope variability.

\section{Geology and hydrogeology of the study area}

The Gwda catchment $\left(4,943 \mathrm{~km}^{2}\right)$ is located in western Pomerania (northern Poland). Groundwater flow in deep aquifers generally takes place towards the south (with the exception of the Gwda valley), in the direction of the mouth of the River Gwda where it flows into the Noteć River.

A map of the groundwater level for deep aquifers is presented in Fig. 1. Unfortunately, there are no reliable data to determine the groundwater level within the deep aquifers in the western and northern parts of the study area. The research was conducted on deep aquifers - mainly the Miocene and Lower Pleistocene ones; locally, the latter has a direct connection with the Miocene aquifer (Fig. 2).

The Miocene aquifer occurs within strata assigned to the Krajenka and Adamów formations, which are primarily represented by terrestrial deposits (Piwocki \& Ziembińska-Tworzydło, 1997). The rock matrix of the Miocene aquifer consists of quartz sands and silts, usually with abundant mica flakes and coal dust. The Pleistocene aquifer is sit-

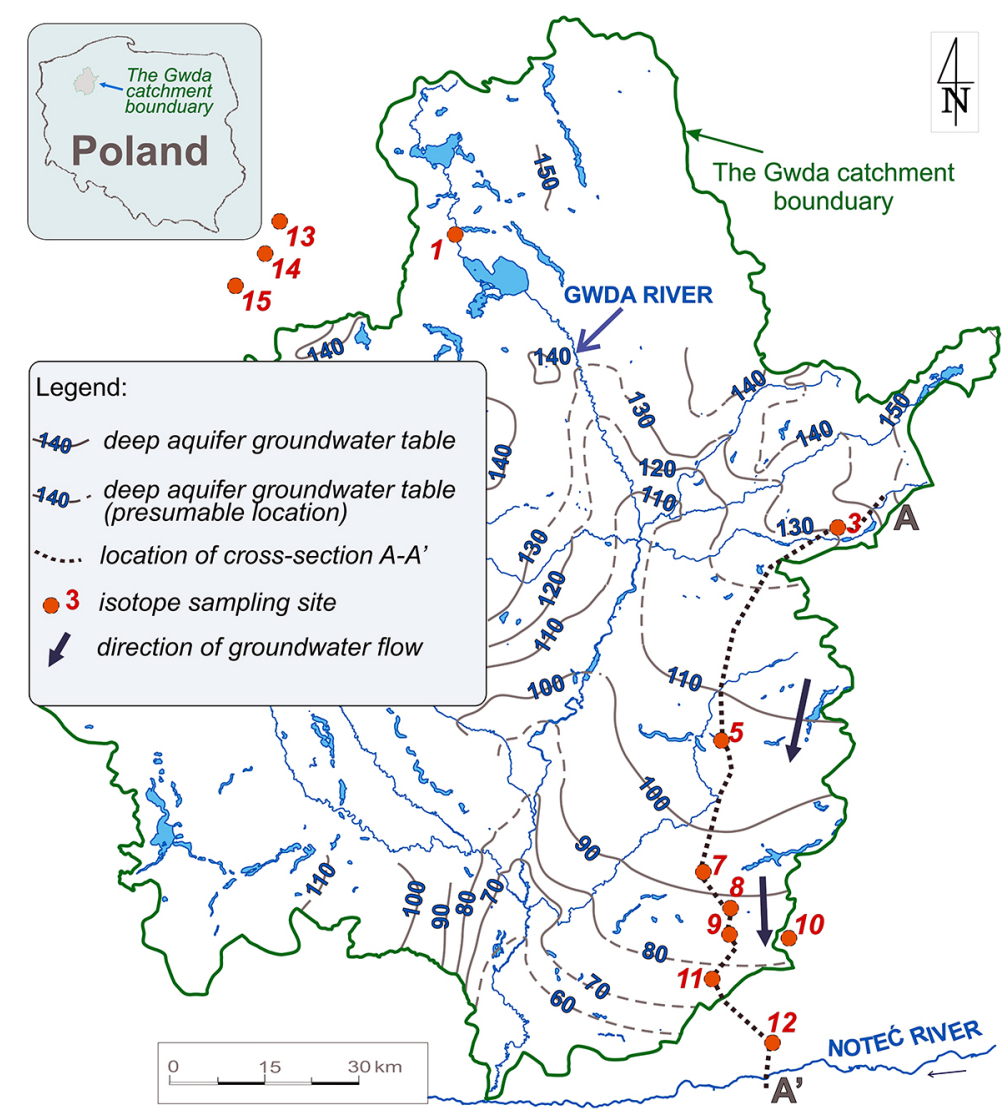

Fig. 1. The deep-aquifer, piezometric level and location of isotope sampling sites (modified from Kotowski \& Śmietański, 2010). 
uated in glaciofluvial sands and gravels as well as glaciolacustrine sands and silts. Calcite content in Pleistocene sediments (tills) is about 10-14 per cent (Górska, 2002). Despite the distinct lithology and genesis of aquifer deposits the deep Pleistocene aquifer was considered together with the Miocene one as a common element in the groundwater circulation system. Irrespective of variable thicknesses, the Miocene aquifer is characterised by a significant extent and continuity. It extends across almost the entire study area with the exception of a deeply eroded, buried valley. Locally, Miocene deposits have been completely or almost completely removed and replaced with sandy Pleistocene deposits. There are numerous erosion-buried valleys in the entire study area (Fig. 3). In most cases, these valleys allow groundwater flow between different aquifers. There are numerous glaciotectonic structures (deformation), which may merge with various aquifers in the northern part of the study area. A broader description of hydrogeological conditions within the study area was presented in previous papers on this region (e.g., Kotowski \& Kachnic, 2007). The formative processes of chemical composition of the deep aquifers (Miocene and Lower Pleistocene) are of natural geological character and are conditioned by the current groundwater circulation system. These processes are related to mineral dissolution and percolation of groundwaters from shallow aquifers (Middle and Upper Pleistocene) to deeper ones, without substantial change in chemical composition (Kotowski \& Śmietański, 2010). The ascent of groundwaters from the Mesozoic aquifers is the major process responsible for increased $\mathrm{Cl}^{-}$ion concentration in the Miocene and deep Pleistocene aquifers (Kotowski \& Kachnic, 2007). Pyrite oxidation is the major process responsible for an increase of $\mathrm{SO}_{4}{ }^{2-}$ and $\mathrm{Ca}^{2+}$ ions within a study area. For a more detailed discussion of groundwater chemistry in the study area, reference is made to Kotowski (2011).

\section{Material and methods}

\subsection{Hydrochemical data}

The chemical composition of groundwater was estimated on the basis of the outcome of the analysis of groundwater samples collected during implementation of the Hydrogeological Map of Poland (HMP), scale 1:50,000. Electric conductivity and $\mathrm{pH}$ were measured in situ. The $\mathrm{HCO}_{3}^{-}$ion concentration was measured directly in the field by titration using $0.1 \mathrm{M} \mathrm{HCl}$, in the presence of a WTW $\mathrm{pH}$ indi- cator. Samples collected for chemical analyses were immediately passed through a $0.45-\mu \mathrm{m}$ membrane filter into polyethylene bottles and kept refrigerated until analysed. Sample for cations (acidification using a few drops of concentrated $\mathrm{HNO}_{3}$ ), anions, alkalinity and TOC (Total Organic Carbon) analyses were preserved in bottles (collectively about 250 $\mathrm{dm}^{3}$ ). Chemical analyses were conducted between 2003 and 2010, by the accredited laboratory of the Polish Geological Institute at Warsaw.

The major dissolved elements were analysed (analytical uncertainty up to \pm 15 per cent) by ICPOES (inductively coupled plasma optical emission spectrometry) method with an iCAP 6500 DUO (Thermo-Scientific) or Panorama V (Jobin-Yvon). Concentrations of anions were analysed (analytical uncertainty up to \pm 15 per cent) by high-performance liquid chromatography HPLC (high-performance liquid chromatography with UV, conductivity, fluorescence and diode array detection) method with an Ion Chrom or Aliance (Waters). TOC was determined by Pastel UV with Oxi UV 50 (Secomam) (analytical uncertainty up to \pm 15 per cent).

\subsection{Isotope data}

Wells were sampled under pressure to avoid sample degassing. For sampling groundwater, sampling system for He concentration measurement has been used. During the collection of groundwater samples, the dissolved oxygen $\left(\mathrm{O}_{2}\right)$ concentration in the groundwater was measured so as to check the air tightness of the sampling system. A detailed descriptive diagram of the system for groundwater sampling was presented by Najman \& Śliwka (2013), to which reference is made. Groundwater samples $\left(\delta^{18} \mathrm{O}, \delta \mathrm{D}\right.$ and tritium) were collected in polyethylene vessels with a capacity of $1.5 \mathrm{dcm}^{3}$, filled to the top, with no headspace, no sample filtration or preservation. During sampling, storage and transportation to the laboratory, we were careful not to expose samples to the atmosphere or evaporation. Groundwater samples for $\mathrm{d}^{13} \mathrm{C}_{\text {DIC }}$ and ${ }^{14} \mathrm{C}$ analyses were collected in polyethylene bottles with a capacity of $30 \mathrm{dcm}^{3}$, with no headspace. We added about $50 \mathrm{~cm}^{3}$ of carbonate-free concentrated $\mathrm{NaOH}$ to raise the $\mathrm{pH}$ of the sample and avoid contamination of the sample by atmospheric $\mathrm{CO}_{2}$.

Determinations of groundwater samples were conducted in the laboratory of the Faculty of Physics and Applied Computer Science AGH-UST at Kraków in 2006-2008. The isotope composition of samples $\left(\delta^{18} \mathrm{O}, \delta^{2} \mathrm{H}\right.$ and $\left.\delta^{13} \mathrm{C}_{\mathrm{DIC}}\right)$ was determined on a Finnigan MAT 251 Ratio Mass Spectrometer. The 


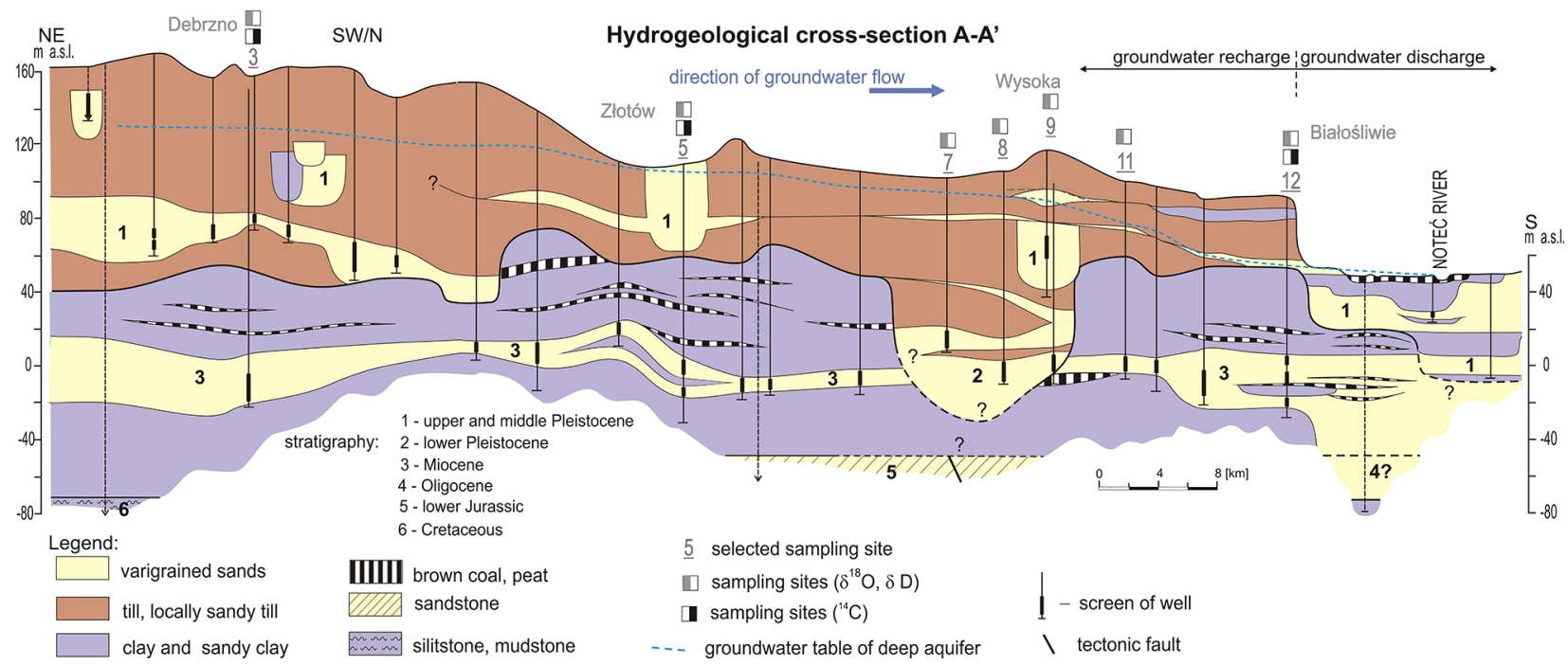

Fig. 2. Hydrogeological cross section of the study area (modified from Kotowski \& Najman, 2015).

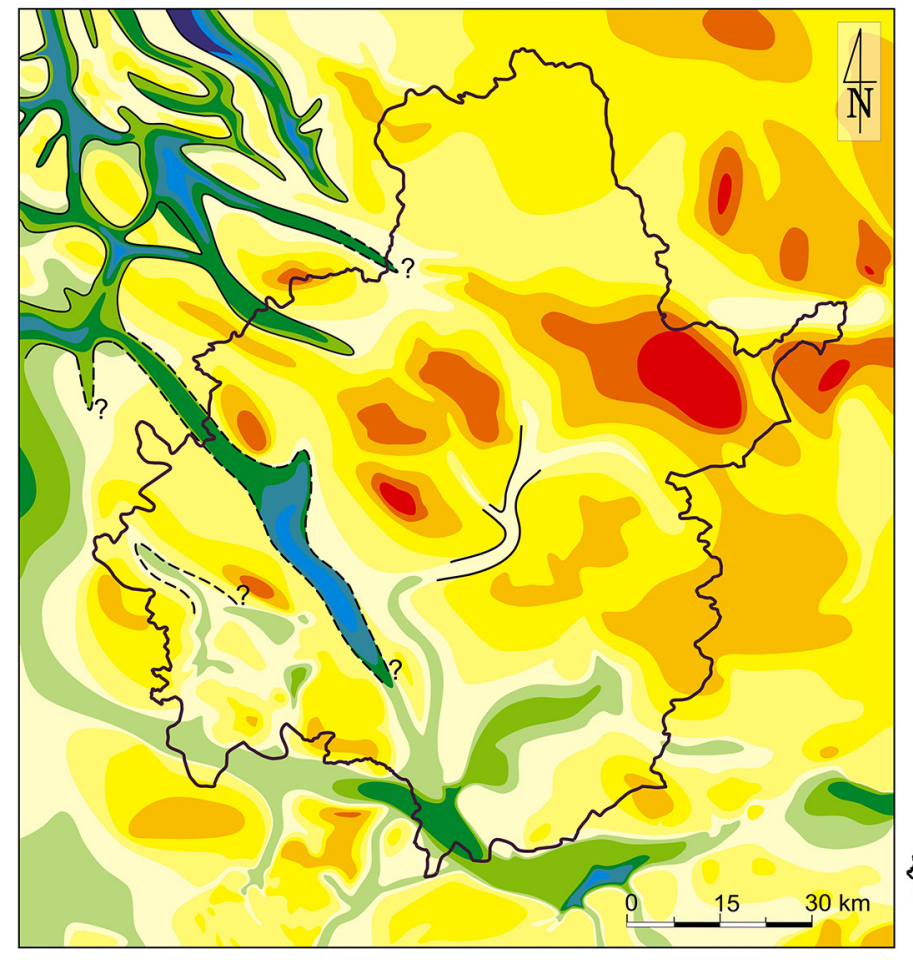

Elevation of Neogene deposits

[m a.s.l.]

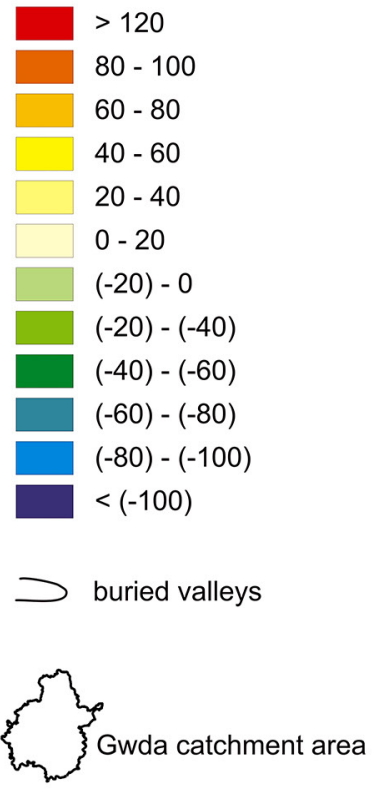

Fig. 3. Relief of Neogene sediments (modified from Kotowski \& Satora, 2012).

isotope ratios of sampled groundwater were measured using the $\mathrm{CO}_{2}-\mathrm{H}_{2} \mathrm{O}$ equilibration method for oxygen, and the $\mathrm{H}_{2}-\mathrm{H}_{2} \mathrm{O}$ equilibration method for hydrogen. Oxygen and hydrogen isotope results are recorded in per mill (\%o) relative to VSMOW (Vienna Standard Mean Ocean Water) and normalised (Coplen, 1994) on scales such that oxygen and hydrogen isotope values of SLAP (Standard Light Antarctic Precipitation) were $-55.5 \%$ ond $-427.5 \%$, respectively. The combined standard uncertainty was estimated at $\pm 0.02 \%$ ond $\pm 0.3 \%$ o for $\delta^{18} \mathrm{O}$ and $\delta \mathrm{D}$, respectively. The activity of tritium was determined by the electrolytic enrichment method (e.g., Gröning \& Rozanski, 2003), the precision of tritium activity measurements was $\pm(0.3 \div 0.5)$. The carbonate stable isotope standard TS-Limestone (NBS-19), with a known $\delta^{13} \mathrm{C}_{\text {DIC }}$ value $(+1.95 \%$ o \pm 0.2 $\%$ ) and known $\delta^{18} \mathrm{O}(-2.2 \%$ o $\pm 0.2 \%$, were used to calibrate $\delta^{13} \mathrm{C}_{\text {DIC }}$ measurements (Friedman et al., 1982). Activities of ${ }^{14} \mathrm{C}$ were conducted by using the LSC method (Liquid Scintillation Counting) with GPC (Gas Proportional Counters). The uncertainty was estimated at $\pm(0.76 \div 1.33)$ pmC (depending on the number of counts) (Gorczyca et al., 1998). 


\section{Results and discussion}

A comparison of the basic geochemical parameters of groundwaters from Miocene and Lower Pleistocene as well as Middle and Upper Pleistocene aquifers is presented in Table 1. The chemical composition of groundwater from deep (Miocene and Lower Pleistocene, $\mathrm{n}=101$ ) and shallow aquifers (Middle and Upper Pleistocene, $n=218$ ) is similar. In most cases concentrations of the main ions, i.e., $\mathrm{HCO}_{3}^{-}, \mathrm{Ca}^{2+}, \mathrm{Mg}^{2+}, \mathrm{Na}^{+}$and $\mathrm{K}^{+}$(and also, to some extent, $\mathrm{SO}_{4}{ }^{2-}$ and $\mathrm{Cl}^{-}$ions) in groundwater from deep and shallow aquifers within the study area are closely similar. Differences between average values of TDS (Total Dissolved Solids) for shallower and deeper aquifers typically fall within the 5-10 per cent range (difference ratios being 1.01 (mean) and 1.04 (median)). The difference ratios for ions $\left(\mathrm{HCO}_{3}^{-}, \mathrm{Ca}^{2+}, \mathrm{Mg}^{2+}, \mathrm{Na}^{+}\right.$and $\left.\mathrm{K}^{+}\right)$fall within the $0.85 \div 1.19$ and $0.88 \div 1.33$ ranges (mean and median, respectively), while those for other major ions $\left(\mathrm{NO}_{3}^{-}, \mathrm{SO}_{4}{ }^{2-}\right.$ and $\left.\mathrm{Cl}^{-}\right)$fall within the $0.08 \div 0.41$ and $0.22 \div 0.42$ ranges (mean and median, respectively). The primary factor that differentiates groundwater chemistry in these aquifers are the elevated concentrations of $\mathrm{SO}_{4}{ }^{2-}, \mathrm{Cl}^{-}$and, in part, also $\mathrm{NO}_{3}{ }^{-}$ions in shallow aquifers, which are mostly related to the inflow of groundwater polluted by humans. There are numerous areas with high concentrations of $\mathrm{SO}_{4}{ }^{2-}, \mathrm{Cl}^{-}$and $\mathrm{NO}_{3}{ }^{-}$(more than 75, 30 and $10 \mathrm{mg} / \mathrm{l}$, respectively; see Kotowski, 2009).

Results nos. 13-15 (Table 2) apply to isotope analyses carried out in 1997 for the northwestern part of the Gwda catchment and the adjacent area (Wiśniowski, 1998). Detailed characterisations of the wells sampled are presented in Table 2.

Table 1. Comparison of basic geochemical parameters of groundwaters from Miocene and Lower Pleistocene $(\mathrm{n}=101)$ as well as Middle and Upper Pleistocene aquifers $(n=218)$.

\begin{tabular}{|c|c|c|c|c|c|c|c|}
\hline \multirow{2}{*}{$\begin{array}{c}\text { Aquifer } \\
\text { Parameters }^{1)} \\
\end{array}$} & \multirow[t]{2}{*}{$\begin{array}{c}\text { Uncertainty } \\
{[\%]}\end{array}$} & \multicolumn{2}{|c|}{$\begin{array}{c}\text { Miocene and Lower } \\
\text { Pleistocene } \\
n=101\end{array}$} & \multicolumn{2}{|c|}{$\begin{array}{l}\text { Middle and Upper } \\
\text { Pleistocene } \\
\text { n=218 }\end{array}$} & \multicolumn{2}{|c|}{$\begin{array}{c}\text { Differences ratio between } \\
\text { aquifers }{ }^{2)} \\
{[-]}\end{array}$} \\
\hline & & Mean & Median & Mean & Median & Mean & Median \\
\hline TDS & - & 395 & 386 & 391 & 372 & 1.01 & 1.04 \\
\hline TOC & \pm 1.0 & 2.8 & 2.2 & 3.1 & 2.2 & 0.90 & 1.00 \\
\hline $\mathrm{HCO}_{3}^{-}$ & 20 & 263 & 261 & 221 & 209 & 1.19 & 1.25 \\
\hline $\mathrm{SO}_{4}^{2-}$ & \pm 0.5 & 11.2 & 6.7 & 37.7 & 30.6 & 0.30 & 0.22 \\
\hline $\mathrm{Cl}^{-}$ & \pm 0.5 & 6.8 & 5.0 & 16.6 & 12.0 & 0.41 & 0.42 \\
\hline $\mathrm{NO}_{3}^{-}$ & \pm 0.01 & 0.12 & 0.07 & 1.57 & 0.20 & 0.08 & 0.35 \\
\hline $\mathrm{NH}_{4}^{+}$ & \pm 0.05 & 0.24 & 0.16 & 0.11 & 0.04 & 2.18 & 4.00 \\
\hline $\mathrm{Ca}^{2+}$ & \pm 0.1 & 73.4 & 72.2 & 78.3 & 75.0 & 0.94 & 0.96 \\
\hline $\mathrm{Mg}^{2+}$ & \pm 0.1 & 9.2 & 8.1 & 8.2 & 7.4 & 1.12 & 1.09 \\
\hline $\mathrm{Na}^{+}$ & \pm 0.5 & 7.1 & 5.8 & 8.4 & 6.6 & 0.85 & 0.88 \\
\hline $\mathrm{K}^{+}$ & \pm 0.1 & 1.7 & 1.6 & 1.9 & 1.2 & 0.89 & 1.33 \\
\hline
\end{tabular}

${ }^{1}$ The Total Dissolved Solids (TDS), Total Organic Carbon (TOC) and ion concentrations are given in mg/l.

${ }^{2}$ Differences ratios between aquifers are calculated as a value for Miocene and Lower Pleistocene aquifer divided by the value of Upper Pleistocene aquifer.

Table 2. Characteristics of wells that were selected for isotope studies.

\begin{tabular}{|rllccc} 
No. & Localization & Stratigraphy & $\begin{array}{c}\text { Depth of well } \\
{[\mathrm{m}]}\end{array}$ & $\begin{array}{c}\text { Depth of aquifer top } \\
{[\mathrm{m}]}\end{array}$ & $\begin{array}{c}\text { Depth of well screen center } \\
{[\mathrm{m}]}\end{array}$ \\
\hline 1 & Spore & Miocene & 220 & 174 & 185 \\
\hline 3 & Debrzno & Miocene & 194 & 149 & 177 \\
\hline 5 & Złotów & Miocene & 146 & 126 & 133 \\
8 & Bądecz & Pleistocene & 116 & 103 & 108 \\
\hline 9 & Wysoka & Pleistocene & 80 & 40 & 67 \\
10 & Młotkowo & Pleistocene & 93 & 70 & 84 \\
12 & Białośliwie & Miocene & 115 & 82 & 96 \\
13 & Górki & Pleistocene & 138 & 127 & 134 \\
\hline 14 & Stary Chwalim & Pleistocene & 42 & 20 & 36 \\
\hline 15 & Barwice & Miocene & 111 & 83 & 103 \\
\hline
\end{tabular}

${ }^{1}$ Depth of top of shallow Pleistocene aquifer is below $100 \mathrm{~m}$. 
Table 3. Results of determinations of $\delta^{18} \mathrm{O}, \delta^{2} \mathrm{H}$ and activity of tritium.

\begin{tabular}{|c|c|c|c|c|c|c|c|}
\hline No & $\begin{array}{l}\text { Sampling } \\
\text { date }\end{array}$ & Localization & $\begin{array}{c}\mathrm{O}_{2} \\
{[\mathrm{mg} / \mathrm{l}]}\end{array}$ & $\begin{array}{c}\mathrm{T} \\
{\left[{ }^{\circ} \mathrm{C}\right]}\end{array}$ & $\begin{array}{c}\delta^{18} \mathrm{O} \\
{[\% \text { o] }} \\
\text { V-SMOW }\end{array}$ & $\begin{array}{c}\delta \mathrm{D} \\
{[\% \text { ] }} \\
\text { V-SMOW }\end{array}$ & $\begin{array}{c}\text { Tritium } \\
\text { activity } \\
\text { [T.U.] }\end{array}$ \\
\hline 1 & 04.06 .07 & Spore (1) & 0.79 & 11.6 & -9.3 & $\begin{array}{l}-64.6 \\
-64.9\end{array}$ & not measured \\
\hline 3 & 29.05 .07 & Debrzno & 0.59 & 10.0 & $\begin{array}{l}-9.4 \\
-9.4\end{array}$ & -66.0 & not measured \\
\hline 5 & 03.11 .06 & Złotów & 0.20 & 10.5 & -9.4 & $\begin{array}{l}-65.8 \\
-64.9\end{array}$ & $0 \pm 0.3$ \\
\hline 5 & 29.05 .07 & Złotów & - & - & -9.2 & -67.9 & not measured \\
\hline 8 & 03.11 .06 & Bądecz & - & - & -8.9 & $\begin{array}{l}-64.2 \\
-63.7\end{array}$ & $0 \pm 0.3$ \\
\hline 9 & 20.11 .07 & Wysoka & 0.30 & 10.5 & -9.4 & -66.1 & $0 \pm 0.3$ \\
\hline 10 & 03.11 .06 & Młotkowo & - & - & -9.6 & $\begin{array}{l}-67.1 \\
-67.3\end{array}$ & $0.5 \pm 0.3$ \\
\hline 12 & 29.05 .07 & Białośliwie & 0.35 & 11.0 & $\begin{array}{l}-8.1 \\
-8.2 \\
-8.2\end{array}$ & $\begin{array}{l}-62.8 \\
-61.9\end{array}$ & not measured \\
\hline 13 & 23.05 .97 & Górki & - & - & $\begin{array}{l}-9.3 \\
-9.3\end{array}$ & $\begin{array}{l}-64.8 \\
-65.0\end{array}$ & $1.2 \pm 0.5$ \\
\hline 14 & 23.05 .97 & Stary Chwalim & - & - & $\begin{array}{l}-9.4 \\
-9.4\end{array}$ & $\begin{array}{l}-65.4 \\
-65.6\end{array}$ & $0.1 \pm 0.5$ \\
\hline 15 & 23.05 .97 & Barwice & - & - & $\begin{array}{l}-9.4 \\
-9.5\end{array}$ & $\begin{array}{l}-64.6 \\
-64.3\end{array}$ & $0.2 \pm 0.5$ \\
\hline
\end{tabular}

Results of $\delta^{18} \mathrm{O}$ determinations (Table 3; Fig. 4) indicate the presence at considerable depths $(>100$ $\mathrm{m}$ ) of groundwater with an isotope composition that is indicative of infiltration during the Holocene.

Results of $\delta^{18} \mathrm{O}$ and $\delta \mathrm{D}$ for samples nos. 1, 3 and $5\left(\delta^{18} \mathrm{O}\right.$ also in sample 13$)$ are very similar to average values of the isotope composition of infiltration water recharged in this area during the Holocene (-9.6 and -65.7, respectively; see d'Obyrn et al., 1997).
The $\delta^{18} \mathrm{O}$ determinations are characterised by low variability (excepting for samples 8 and 12). A small difference in $\delta^{18} \mathrm{O}$ is likely to have resulted from the infiltration of water during different climatic periods, with a c. 0.5-1.0 degree amplitude of long-term average temperatures.

In the graph (Fig. 5), $\delta^{18} \mathrm{O}$ and $\delta \mathrm{D}$ in most cases are concentrated around the WMWL (World Meteoric Water Line) line as determined by the equation:

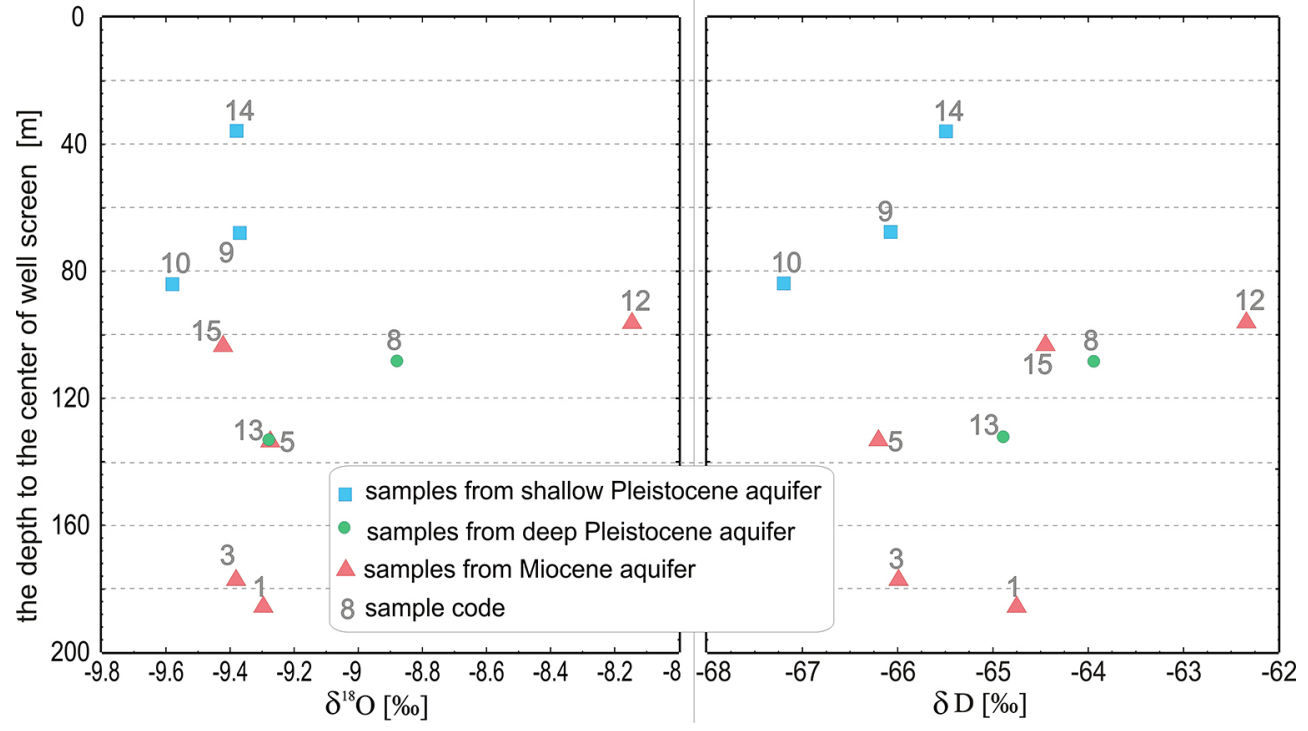

Fig. 4. $\delta^{18} \mathrm{O}$ and $\delta \mathrm{D}$ values as a function of well filtering depth, $\mathrm{n}=10$ (compare Table 2). 
Fig. 5. The $\delta \mathrm{D}$ vs $\delta^{18} \mathrm{O}$ plot and activity of tritium, $\mathrm{n}=10$ (compare Table 1).

$\delta \mathrm{D}=8 * \delta^{18} \mathrm{O}+10$ (Craig, 1961). Only two samples, 8 and 12, are clearly spaced away from that line. This clear enrichment with heavy isotopes of the groundwater from Białośliwie (sample 12) presumably is the result of partial evaporation of this water prior to the infiltration process. This is a phenomenon that is frequently observed for groundwater in Pleistocene aquifers that were recharged during the Holocene (Zuber et al., 1990). The evaporation effect is related to the existence of numerous lakes and marginal areas during the Holocene. Surface waters from such water bodies could have recharged groundwater; they were preserved in large aquifer systems (Zuber et al., 1990).

Values of $\delta^{18} \mathrm{O}$ and $\delta \mathrm{D}(-8.9 \%$ and $-64.0 \%$ obtained for sample 8 are similar to those from Lower Jurassic aquifers, which are $-8.8 \%\left(\delta^{18} \mathrm{O}\right)$ and $-62.4 \%$ o $(\delta \mathrm{D})$, respectively (Krawiec, 2005).
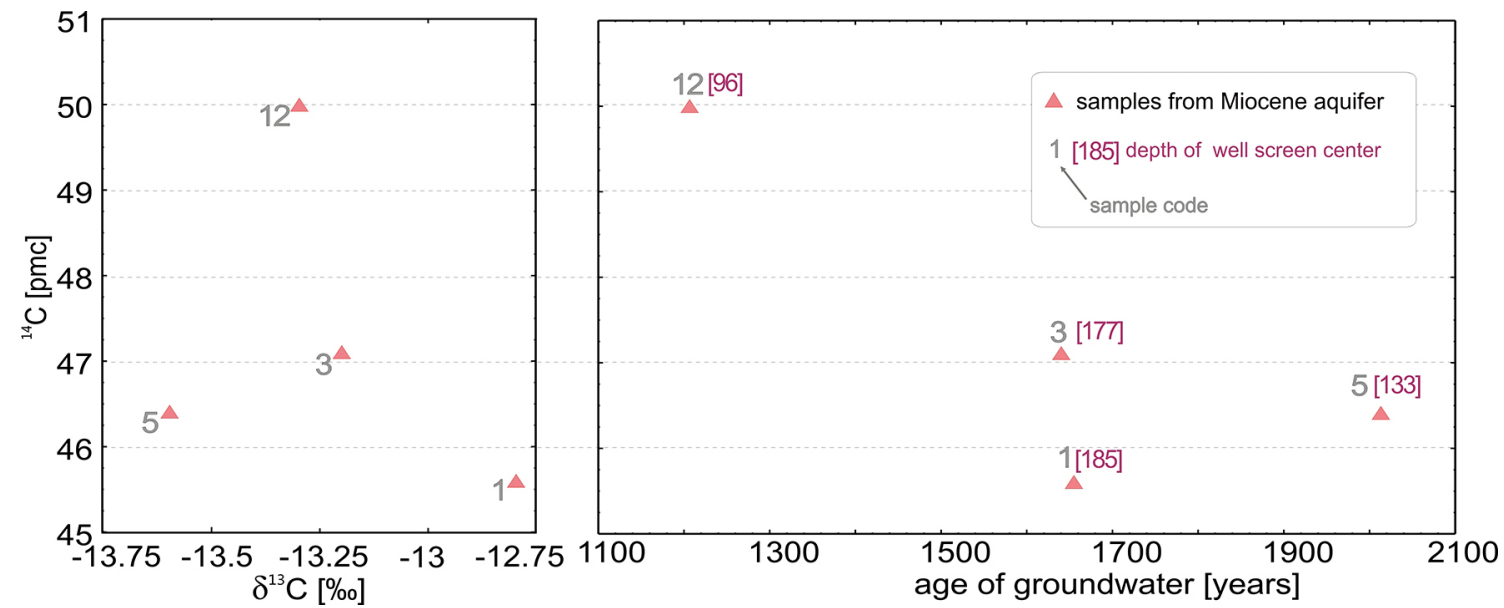

Fig. 6. Measurements of $\delta^{13} \mathrm{C}_{\mathrm{DIC}}$ and ${ }^{14} \mathrm{C}$ activity and groundwater ages, $\mathrm{n}=4$ (compare Table 2). 
Table 4. Results of determination of $\delta^{13} \mathrm{C},{ }^{14} \mathrm{C}, \mathrm{HCO}_{3}^{-}$ions concentrations and age of groundwaters.

\begin{tabular}{rrlccccc}
\hline No & Sampling data & Localization & $\begin{array}{c}\delta^{13} \mathrm{C} \\
{[\%]}\end{array}$ & $\begin{array}{c}{ }^{14} \mathrm{C} \\
{[\mathrm{pmc}]}\end{array}$ & $\begin{array}{c}\mathrm{HCO}_{3}^{-} \\
{[\mathrm{mg} / \mathrm{l}]}\end{array}$ & $\begin{array}{c}\text { Age of } \\
\text { V-PDB }\end{array}$ & $\begin{array}{c}\text { Model } \\
\text { groundwater } \\
\text { [years] }\end{array}$ \\
\hline 1 & 04.06 .07 & Spore (1) & -12.8 & $45.6 \pm 1.0$ & 259 & piston flow & 1700 \\
3 & 29.05 .07 & Debrzno & -13.2 & $47.1 \pm 1.0$ & 338 & piston flow & 1600 \\
\hline 5 & 29.05 .07 & Złotów & -13.6 & $46.4 \pm 1.0$ & 367 & piston flow & 2000 \\
12 & 29.05 .07 & Białośliwie & -13.3 & $50.0 \pm 1.0$ & 484 & piston flow & 1200 \\
\hline
\end{tabular}

Ages of groundwater are rounded to the 100 years.

The following equation was applied to calculations of the age of groundwater as based on the ${ }^{14} \mathrm{C}$ content determined (according to Clark \& Fritz, 1997):

Age [thous. years] $\cong 8300 \cdot \ln \left[\frac{\delta^{13} C_{D I C}-\delta^{13} C_{C a C O 3}}{\delta^{13} C_{\text {soil }}-\delta^{13} C_{\mathrm{CaCO}}} \cdot \frac{C_{o}}{{ }^{14} C}\right]$ where:

$C_{o}=$ initial ${ }^{14} \mathrm{C}$ content (usually taken as 100 per cent of recnet carbon);

${ }^{14} \mathrm{C}=$ measured value;

$\delta^{13} C_{\text {DIC }}=$ value determined for total dissolved inorganic carbon;

$\delta^{13} C_{\mathrm{CaCO} 3}=$ adopted value $(0 \%)$ for ${ }^{14} \mathrm{C}$-free carbon minerals and rocks subjected to dissolution and isotope exchange during the dissolution phase;

$\delta^{13} C_{\text {soil }}=$ adopted value $(-23 \%)$ for soil $\mathrm{CO}_{2}$ modified by isotope fractionation during diffusional transport, assuming an open system for (soil) $\mathrm{CO}_{2}$.

A value of $\delta^{13} \mathrm{C}_{\text {soil }}=-23 \%$ was adopted on the basis of results of isotope analyses of soil $\mathrm{CO}_{2}$ flux (Gorczyca et al., 2003; Gamnitzer et al., 2011). This value includes the effect of, among other factors, the enrichment of soil $\mathrm{CO}_{2}$ with heavier isotopes during its diffusive migration into the aeration zone. According to some authors, the diffusion process itself may result, at greater depths, in enrichment of soil carbon dioxide with heavier isotopes, reaching levels as high as c. $8.7 \%$ as compared to the $\mathrm{CO}_{2}$ present in the stream flowing from the soil (Amundson et al., 1998; Stern et al., 1999). It should be noted that in every case the age of groundwater, calculated using equation 1 and the often assumed value $\delta^{13} C_{\text {soil }}$ $=-25 \%$ o, is c. 692 years less. This result (ca. 700 yrs) is exceeding the potential error related to the accuracy of groundwater age estimation. Assuming uncertainties of ${ }^{14} \mathrm{C}$ to be around $\pm 1 \mathrm{pmC}$, that of the age of groundwater can be calculated (assuming a piston flow model) to be $c .210$ or c. 250 years for uncertainties of $\delta^{13} C_{D I C}$ equal to \pm 0.1 or $\pm 0.2 \%$, respectively.

Considering sampling depth (Table 2) and the relatively large distance between the sampling points (Fig. 1), variation of $\delta^{13} \mathrm{C}_{\text {DIC }}$ and ${ }^{14} \mathrm{C}$ values is low. Differences between ${ }^{14} \mathrm{C}$ values (except for sample 12) slightly exceed the uncertainty (determination error), which is $\pm 1.0 \mathrm{pmC}$. It should be noted that $1 \mathrm{pmC}$ is the uncertainty that represents

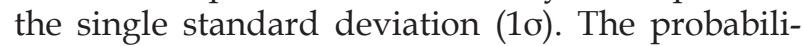
ty is that true values lie in the range $\pm 1 \sigma$ is c. $66 \%$. For the $\pm 2 \sigma$ range it rises to 95 per cent. Thus, with a likelihood of 95 per cent, practically all ${ }^{14} \mathrm{C}$ values are identical. The difference between the maximum and minimum values for the $\delta^{13} \mathrm{C}$ determinations is only $0.8 \%$.

Average activity of ${ }^{14} \mathrm{C}$ is twice higher than the activity of ${ }^{14} \mathrm{C}$ determined under similar conditions and hydrogeological systems (e.g., upper Serravallian sands and buried Pleistocene valleys of the Kędzierzyn-Głubczyce Subtrough) where the average activity of ${ }^{14} \mathrm{C}$ is 24.81 pmC (Duliński et al., 2002; Witczak et al., 2007). $\delta^{13} C_{\text {DIC }}$ values obtained fall within the $-13.6 \%$ o to $-12.8 \%$ range, which, according to Clark \& Fritz (1997), possibly indicates contribution from both degradation of organic matter and a carbonate source (50 per cent each). In the Miocene terrestrial strata calcite has not been found or occurs sporadically (merely at brackish levels) and its share usually is a few percent (Stoiński, 2004; Wągrowski, 2005). Despite the small number of samples, the lack of more negative $\delta^{13} \mathrm{C}_{\text {DIC }}$ values (below $-15 \%$ ) rather excludes the possibility of carbon isotope modification through decomposition of organic matter in the aquifer. In most cases $\delta^{13} \mathrm{C}_{\text {DIC }}$ values for different kinds of organic matter are markedly below -20\% (Gorczyca et al., 2013). Obtained $\delta^{13} \mathrm{C}_{\mathrm{DIC}}$ values likely indicate moderate levels of organic matter decomposition, mainly of detrital humus and xyloid coal commonly occurring in terrestrial Miocene sedimentary rocks (Kasiński et al., 2002; Piwocki, 2004). Additionally, low organic carbon content - the average TOC being $2.8 \mathrm{mg} / 1$ $(n=55)$ - in samples from the Miocene aquifers presumably implies low activity of organic matter decomposition. The average TOC in Miocene levels does not differ much from the average TOC determined for Pleistocene aquifers, the average of which is $3.1 \mathrm{mg} / 1(\mathrm{n}=218)$. 
Results of $\delta^{13} \mathrm{C}_{\mathrm{DIC}}$ and activity of ${ }^{14} \mathrm{C}$ for sample 12 show a slightly different isotope composition in comparison to the remaining determinations. Activity of ${ }^{14} \mathrm{C}$ found in sample 12 is the highest for the samples examined, despite the fact that, given the hydrogeological conditions and the direction of groundwater flow in the Miocene aquifer, one would have expected the lowest value. Modification of $\delta^{13} \mathrm{C}_{\mathrm{DIC}}$ and activity ${ }^{14} \mathrm{C}$ as a result of isotope exchange between dissolved carbonates and rock matrix carbonates is in this case unlikely, because such exchange leads to a reduction in ${ }^{14} \mathrm{C}$ activity. The $\mathrm{d}^{13} \mathrm{C}_{\text {DIC }}$ in this case is significantly affected by specific hydrogeological and hydrogeochemical conditions. The Miocene and Oligocene aquifers are in full hydraulic connection with aquifers in the Pleistocene sandy sediments that fill the Noteć valley (see Fig. 2). In relation with the above observations, it was assumed that the determined $\delta^{13} \mathrm{C}_{\mathrm{DIC}}$ and activity ${ }^{14} \mathrm{C}$ in sample 12 are likely the result of mixing groundwater of different origin. Apparently the groundwater from the Miocene aquifer mixed with groundwater from Oligocene and shallow Pleistocene aquifers within the Noteć buried valley area. Considering the slight difference between calibrated and uncalibrated groundwater ages for a range of 1200-2000 years (little below or the same as the precision of dating) the calibration was omitted.

Taking into account the extent of the study area and hydrogeological conditions a weak differentiation is observed when considering all isotope and hydrochemical data. A relatively small variability in the isotope composition of groundwater likely indicates a considerable value of vertical component of the groundwater flow in the recharge zone (in the upland area). It is likely related to significant vertical (or near-vertical) percolation of groundwater into deeper aquifers through confining layers.

\section{Conclusions}

Groundwater from deep aquifers in our study area could have been affected by anthropogenic pollution (i.e., high concentrations of $\mathrm{NO}_{2}^{-}, \mathrm{NO}_{3}^{-}$ $\mathrm{SO}_{4}^{2-}$ and $\mathrm{Cl}^{-}$ions). It is related to the possibility of inflow of groundwater to deep aquifers, which often are in connection with shallower aquifers and which are polluted by man. Concentrations of the majority ions in shallow and deep aquifers are very similar. The difference ratios for ions $\left(\mathrm{HCO}_{3}{ }^{-}, \mathrm{Ca}^{2+}\right.$, $\mathrm{Mg}^{2+}, \mathrm{Na}^{+}$and $\mathrm{K}^{+}$) fall within $0.85 \div 1.19$ and $0.88 \div 1.33$ ranges (mean and median, respectively). Significant differences between other ions concentrations
$\left(\mathrm{NO}_{3}^{-}, \mathrm{SO}_{4}{ }^{2-}\right.$ and $\left.\mathrm{Cl}^{-}\right)$for shallower and deeper aquifers are related to anthropogenic pollution. The difference ratios for ions $\left(\mathrm{NO}_{3}^{-}, \mathrm{SO}_{4}{ }^{2-}\right.$ and $\left.\mathrm{Cl}^{-}\right)$fall within $0.08 \div 0.41$ and $0.22 \div 0.42$ ranges (mean and median, respectively).

Values of $\delta^{18} \mathrm{O}$ and $\delta^{2} \mathrm{H}$ are similar $(-9.6 \div-8.1 \%$ o and $-67.9 \div-61.9 \%$, respectively) both for Miocene and deep Pleistocene and shallower aquifers. The results of $\delta^{18} \mathrm{O}$ determinations indicate the presence at considerable depths $(>100 \mathrm{~m})$ of groundwater with an isotope composition that indicates infiltration during the Holocene, with low (c. 0.5-1.0 degrees) amplitude of long-term average temperatures. In some cases the enrichment of groundwater with heavy isotopes likely is the result of partial evaporation of this water prior to the infiltration process. In general, results of $\delta^{18} \mathrm{O}$ and $\delta \mathrm{D}$ are closely similar to average values of the isotope composition of infiltration water recharged in this part of Poland.

The variability of $\delta^{13} \mathrm{C}_{\mathrm{DIC}}$ and activity ${ }^{14} \mathrm{C}$ are both very low. Differences in most cases between the latter slightly exceed the determination error.

The difference between the maximum and minimum values for $\delta^{13} \mathrm{C}_{\mathrm{DIC}}$ determinations amount to only $0.8 \%$. $\delta^{13} \mathrm{C}_{\mathrm{DIC}}$ values $(-13.6 \div-12.8 \%$ o) obtained likely indicate partial (50 per cent each) contributions from organic matter degradation and from dissolution of carbonates within the rock matrix of aquifers the majority of which is composed of quartz sands, silts and coal dust. Estimated groundwater ages for Miocene aquifers fall within the range from c. 1,200 to $c .2,000$ years.

Deeply incised river valleys and lakes, as well as deep erosion troughs and buried valleys, in this area significantly facilitate percolation of groundwater into deeper aquifers and are also of considerable importance to the groundwater circulation system. Indirectly, the great intensity of vertical percolation is indicated by the significant depth (c. $700 \mathrm{~m}$ ) of active groundwater exchange zone in the immediate vicinity of the River Gwda catchment.

It can be stated that in most cases groundwaters from deep aquifers are similar to recent groundwater in terms of isotope composition. In general, all results indicate the presence of closely similar groundwaters in the system, irrespective of geological formation.

In consideration of the above observations the results of isotope and chemical analyses presumably indicate a significant hydraulic connection between shallow and deep aquifers of the Pleistocene and Miocene in the Gwda catchment. Such a hydraulic connection between shallow and deep aquifers hints at potential seepage of pollutants from 
shallow Pleistocene to deep Miocene aquifers. This can have a negative impact on deep aquifers because over 30 per cent of shallow aquifers within the Gwda catchment are anthropogenically polluted (i.e., high concentrations of $\mathrm{NO}_{3}{ }^{-}, \mathrm{SO}_{4}{ }^{2-}$ and $\mathrm{Cl}^{-}$ ions). Compared to the anthropogenic contamination classification of groundwater as proposed by Górski (2001), in numerous cases the concentration of those significantly exceeds the limit values $\left(\mathrm{NO}_{3}{ }^{-}\right.$ $>10 \mathrm{mg} / 1 ; \mathrm{SO}_{4}{ }^{2-}>100 \mathrm{mg} / 1$ and $\left.\mathrm{Cl}^{-}>50 \mathrm{mg} / \mathrm{l}\right)$.

\section{References}

Amundson, R., Stern, L., Baisden, T. \& Wang, Y., 1998. The isotopic composition of soil and soil-respired $\mathrm{CO}_{2}$. Geoderma 82, 83-114.

Clark, I.D. \& Fritz, P., 1997. Environmental isotopes in hydrogeology. CRS Press, Boca Raton, 328 pp.

Coplen, T.B., 1994. Reporting and stable hydrogen, carbon, and oxygen isotopic abundances. Pure and Applied Chemistry Journal 66, 273-276.

Craig, H., 1961. Isotopic variations in meteoric waters. Science 133 (3465): 1702-1703.

d’Obyrn, K., Grabczak, J. \& Zuber, A., 1997. Mapy składów izotopowych infiltracji holoceńskiej na obszarze Polski [Maps of isotopic composition of the Holocene meteoric waters in Poland]. [In:] J. Górski \& E. Liszkowska (Eds): Wspótczesne problemy hydrogeologii [Contemporary Problems of Hydrogeology] 8, 331-333.

Duliński, M., Kmiecik, E., Opoka, M., Różański, K., Szczepańska, J., Szklarczyk, T., Oliwka, I., Witczak, S. \& Zuber, A., 2002. Hydrochemistry of Kedzierzyn Subtrough aquifer as related to water ages. Prace Wydziatu Nauk o Ziemi Uniwersytetu Śląskiego 22, 35-43.

Friedman, I., O'Neil, J. \& Cebula, G., 1982. Two new carbonate stable isotope standards. Geostandards Newsletter 6, 11-12.

Gamnitzer, U., Moyes, A.B., Bowling, D.R. \& Schnyder, H., 2011. Measuring and modelling the isotopic composition of soil respiration: insights from a grassland tracer experiment. Biogeosciences 8, 1333-1350.

Gorczyca, Z., Jelen, K. \& Kuc, T., 1998. Gas counting system for ${ }^{14} \mathrm{C}$ dating of small samples in the Kraków laboratory. Radiocarbon 40, 129-135.

Gorczyca, Z., Kuc, T. \& Różański, K., 2013. Concentration of radiocarbon in soil-respired $\mathrm{CO}_{2}$ flux: Datamodel comparison for three different ecosystems in southern Poland. Radiocarbon 55, 1521-1532.

Gorczyca, Z., Różański, K., Kuc, T. \& Michalec, B., 2003. Seasonal variability of the soil $\mathrm{CO}_{2}$ flux and its isotopic composition in southern Poland. Nukleonika 48, 187-196.

Górska, M., 2002. Petrography of glacial sediments within the Drawskie Lakeland. [In:] R. Dobracki, J. Lewandowski \& T. Zielinski (Eds): Plejstocen Pomorza Środkowego i strefa marginalna lobu Parsęty [Pleistocene of Middle Pomerania and marginal zone of Parsęta lobe].
Państwowy Instytut Geologiczny \& Uniwersytet Śląski, Sosnowiec, 23-23.

Górski, J., 2001. Propozycje oceny antropogenicznego zanieczyszczenia wód podziemnych na podstawie wybranych wskaźników hydrogeochemicznych [Proposal of anthropogenic contamination evaluation of groundwater on the base of chosen hydrochemical indicators]. [In:] T. Bocheńska \& S. Staśko (Eds): Wspótczesne Problemy Hydrogeologii 10, 309-314.

Gröning, M. \& Rozanski, K., 2003. Uncertainty assessment of environmental tritium measurements in water. Accreditation and Quality Assurance 8, 359-366.

Kachnic, M. \& Kotowski, T., 2004a. Mapa hydrogeologiczna Polski w skali 1:50 000 - arkusz Złotów wraz z objaśnieniami [Hydrogeological Map of Poland, 1:50 000, Złotów sheet with explanations]. Państwowy Instytut Geologiczny, Warszawa.

Kachnic, J. \& Kotowski, T., 2004b. Mapa hydrogeologiczna Polski w skali 1:50 000, arkusz Wysoka wraz z objaśnieniami [Hydrogeological Map of Poland, 1:50 000, Wysoka sheet with explanations]. Państwowy Instytut Geologiczny, Warszawa.

Kasiński, J.R., Czapkowski, G. \& Gąsiewicz, A., 2002. Marine-influenced and continental setting of the Poznań Formation (Upper Neogene, Central and SW Poland). [In:] K. Gürs (Ed.): Northern European Cenozoic Stratigraphy 8, 162-184.

Kotowski, T., 2009. Procesy kształtujące skład chemiczny płytkich poziomów wodonośnych plejstocenu w obszarze zlewni Gwdy [Processes forming the chemical composition of a shallow Pleistocene aquifers within the Gwda river catchment]. Geological Exploration Technology. Geothermics, Sustainable Development 244, 133-149.

Kotowski, T., 2011. Porównanie wybranych statystycznych metod analizy danych hydrogeochemicznych na przykładzie kenozoicznych poziomów wodonośnych w obszarze zlewni Gwdy [Comparison of selected statistical methods of hydrogeochemical data analysis, exemplified by Cenozoic aquifers within the Gwda river basin]. Biuletyn Państwego Instytutu Geologicznego 447, 15-24

Kotowski, T. \& Burkowska, A., 2011. The influence of bacterial reduction on the concentration of sulphates in deep aquifers in a southeastern section of the river Gwda drainage basin, northwestern Poland. Polish Journal of Environmental Studies 20, 379-386.

Kotowski, T. \& Kachnic, M., 2007. Formowanie składu chemicznego wód podziemnych w warstwach miocenu i plejstocenu w rejonie występowania głębokiej doliny kopalnej w pobliżu Wysokiej [The formation of chemical composition of groundwaters from the Miocene and the Pleistocene aquifers within of the buried valley area located in the vicinity of Wysoka]. Biuletyn Państwego Instytutu Geologicznego 427, 47-60.

Kotowski, T. \& Satora, S., 2012. Wody podziemne zlewni Gwdy - struktura wykorzystania i zagrożenia [Groundwater's of Gwda catchment - the utilization and threats]. Gaz, Woda i Technika Sanitarna 2, 81-84.

Kotowski, T. \& Śmietański, L., 2010. Wstępne wyniki badań hydrogeochemicznych, izotopowych i mode- 
lowych wykonanych w zlewni Gwdy [Preliminary results of hydrogeochemistry, isotope and modelling studies within the Gwda river basin]. Biuletyn Państwego Instytutu Geologicznego 442, 121-128.

Kotowski, T. \& Najman, J., 2015. Results of the determination of He in Cenozoic aquifers using the GC method. Groundwater 53, 47-55.

Krawiec, A., 2005. Wyniki badań izotopowych i hydrochemicznych wód leczniczych z otworu wiertniczego Piła IG-1 [Results of the isotopes and hydrochemical investigations of therapeutical waters from Piła IG-1 borehole in Kotuń]. [In:] A. Sadurski \& A. Krawiec (Eds): Wspótczesne Problemy Hydrogeologii 7, 815-818.

Najman, J. \& Śliwka, I., 2013. Rozwój metody jednoczesnego pomiaru stężenia helu, argonu oraz neonu do datowania wód podziemnych [The development of the simultaneous method of helium, argon and neon measurements for the groundwater dating]. Biuletyn Państwego Instytutu Geologicznego 456, 419-424.

Piwocki, M., 2004. Paleogen i neogen Pomorza - profil regionalny i korelacje z obszarami sąsiednimi [The Paleogene and the Neogene of Pomerania - the regional profile and correlations with adjacent areas]. Przeglad Geologiczny 52, 693-694.

Piwocki, M. \& Ziembińska-Tworzydło, M., 1997. Neogene of the Polish Lowlands - lithostratigraphy and pollen-spore zones. Geological Quarterly, 41, 21-40.

Rozporzadzenie Ministra Środowiska z dnia 23 lipca 2008 r. w sprawie kryteriów i sposobu oceny stanu wód podziemnych [Regulation of the Minister of Environment dated 23 July 2008 on the criteria and methods of evaluating the un- derground water conditions]. (Dz.U. 2008, nr 143, poz. 896).

Stern, L., Baisden, W.T. \& Amundson, R., 1999. Processes controlling the oxygen isotope ratio of soil $\mathrm{CO}_{2}$ : Analytic and numerical modeling. Geochimica et Cosmochimica Acta 63, 799-814.

Stoiński, A., 2004. Geological Map of Poland, 1:50 000, sheet 0273 with explanations. Polish Geological Institute, Warsaw.

Wągrowski, A., 2005. Geological Map of Poland, 1:50 000, sheet 0272 with explanations. Polish Geological Institute, Warsaw.

Wiśniowski, Z., 1998. Hydrogeological Map of Poland 1:50 000, sheet 159, Barwice. Polish Geological Institute, Warsaw.

Witczak, S., Szklarczyk, T., Kmiecik, E., Szczepańska, J., Zuber, A., Różański, K. \& Duliński, M., 2007. Hydrodynamic modelling, environmental tracers and hydrochemistry of a confined sandy aquifer (Kędzierzyn-Głubczyce Subtrough, SW Poland). Geological Quarterly 51, 1-16.

Zuber, A., Kozerski, B., Sadurski, A., Kwaterkiewicz, A. \& Grabczak, J., 1990. Origin of brackish waters in the Quaternary aquifer of the Vislula delta. [In:] B. Kozerski \& A. Sadurski (Eds): Proceedings of $11^{\text {th }}$ Salt Water Intrusion Meeting. Wydawnictwo Politechniki Gdańskiej, Gdańsk, 249-262.

Manuscript received: 15 December 2014 Revision accepted: 18 March 2016 